\title{
ENTREVISTA COM MARC CHARRON ${ }^{1}$
}

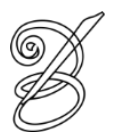 \\ Leomaris Espindola ${ }^{2}$ \\ leomarisw@yahoo.fr \\ Roseni Silva ${ }^{3}$ \\ rosenisilva@yahoo.com.br
}

rofessor Marc Charron, o processo de ruptura política ${ }^{4}$ ocorrido no Canadá, em
1995, influenciou, de alguma forma, a literatura canadense atual?
Marc Charron: Acredito que não, pois a curiosidade de uma parte do país em relação à outra não mudou muito. Infelizmente, não há muito interesse recíproco entre as regiões de língua inglesa e as de língua francesa, pelo menos no que diz respeito à literatura. As pessoas em Montreal, por exemplo, não se importam muito com a literatura de língua inglesa, assim como as pessoas fora do Quebec não se importam muito com a literatura em língua francesa do Quebec. Não sei se a literatura migrante, através do fenômeno de vendas que é a escritora Kim Thúy, ao menos no âmbito do Quebec, vai influenciar mais tarde a literatura no Canadá inglês, que passaria a ver a literatura quebequense de outra forma, a reconhecer a sua tradição e a seus autores de literatura migrante. Mas isso é difícil de prever; acho que a ruptura no Quebec, ao menos a partir de 1995, foi um choque para os anglófonos do Canadá. Eles nunca imaginavam esse resultado e, por isso, foi um choque, mas um choque que passou. Hoje, parte da população inglesa do Canadá diz que, se os quebequenses querem se separar, que se separem. Há quinze anos isso seria impensável, mas hoje eles simplesmente não querem mais se preocupar com isso.

O romance $\mathrm{Ru}$, de Kim Thúy, ${ }^{5}$ vietnamita radicado no Quebec desde 1978, é significativo para a literatura quebequense?

M. C.: Sim, o livro de Kim Thúy é um dos maiores representante da literatura quebequense da última geração, não apenas no Canadá, mas também no exterior. Ele foi traduzido em 12 línguas, em pelo menos 15 países, e acredito que há muito tempo não tínhamos um fenômeno literário como esse, que interessa ao mercado editorial internacional. Embora se trate de uma publicação ainda recente, de 2008, acredito que essa obra pode ser um expoente da literatura 
quebequense no cenário mundial.

\section{Qual a importância da tradução de $\mathrm{Ru}$ ?}

M. C.: Como pesquisador e estudioso da tradução, acredito que $R u$ seja a manifestação literária mais importante dos últimos anos, porque é um exemplo único. Acho também que, ao contrário do que algumas pessoas do Quebec pensam, ou seja, que a literatura quebequense deveria tratar apenas de questões tradicionais, nacionais, essa obra prova que a literatura quebequense contemporânea é multidimensional e exportável, pois, apesar de ser uma literatura em língua francesa, desperta o interesse internacional. A obra de Kim Thúy retrata um percurso vivido por muitas pessoas, no mundo inteiro: a mobilidade em virtude dos problemas causados por guerras civis, como estamos vendo agora, na Síria. O percurso dessas pessoas e o tratamento literário desse percurso são de interesse para a literatura regional, mas também podem ser interesse para outras literaturas de alcance internacional.

É importante questionar por que esse livro, em específico, foi publicado em 15 países específicos e não outros. Há pessoas no Quebec que não querem pensar nessa questão, porque é uma questão difícil de responder, pois essa obra não é uma obra "tipicamente" quebequense. Mas quando eu penso em Montreal e no Quebec de hoje, vejo que ele reflete muito mais o percurso abordado por Kim Thúy, ou seja, multicultural, do que os percursos das famílias tradicionais francófonas [como a minha]. $R u$, de Kim Thúy, é bastante diferente das obras dos anos 1965-1985, que nessa época também privilegiavam, em primeiro plano, a questão identitária, mas sob uma perspectiva política e nacionalista.

Como estudioso da obra de Kim Thúy, a que o professor atribui o sucesso alcançado por Ru? M. C.: Inicialmente, à qualidade literária do livro, mas também ao carisma de Kim Thúy. Ela é muito comunicativa, midiática e transmite suas ideias de maneira clara. Há, no Quebec, a problemática da integração linguística dos imigrantes, mas os vietnamitas, sobretudo as famílias que chegam no fim da década de 1970, levam vantagem por serem francófonos, por terem sido colonizados por franceses. Entretanto, apesar da maioria dos vietnamitas terem chegado ao Quebec sem absolutamente nada, eles sempre se mostraram trabalhadores árduos, muito produtivos; nas escolas sempre se destacaram como os melhores alunos, conseguindo, por consequência, uma afinidade e uma integração com o povo quebequense não apenas no contexto econômico, mas também social. E como Kim Thúy é vietnamita, tudo isso também contribuiu, de certa forma, para o sucesso da sua obra, que retrata, justamente, uma comunidade bem aceita historicamente pela maioria francófona do Quebec. Os quebequenses 
e os vietnamitas tem uma integração exemplar. Uma amostra disso no livro é o relato da acolhida da família de Kim Thúy pelos quebequenses. Estes, por sua vez, se veem bem representados na obra da autora. O livro é escrito em francês, numa escrita bem francesa, bem quebequense, mas possui traços de estrangeirismo, e percebemos um "quê" de diferente, mas tão poético, tão lindo, que a gente gosta e que o leitor é seduzido pelo texto.

Quais são as outras nacionalidades envolvidas nesse processo multicultural da literatura quebequense?

M. C.: Outras culturas estão presentes não apenas na literatura, mas também no cinema quebequense, como no filme Incendies ${ }^{6}$ além disso, existem produções de imigrantes do Vietnã, China (Ying Chen, ${ }^{7}$ ) Índia, Srilanka, Malásia, entre outros países da América Latina. Mas há também autores bem conhecidos da parte inglesa do Canadá, que decidiram, nos últimos anos, morar na parte francesa, na cidade de Quebec, como Neil Bissoondath. Apesar de nascido em Trinidad e Tobago, ele produziu, em inglês, muitas obras que tratam da questão identitária.

Na sua opinião, as diversas traduções de Ru modificam, de alguma forma, a visão identitária que se tem dos canadenses fora do Canadá?

M. C.: Acredito que não. A visão que se tem do canadense, do quebequense, fora do Canadá ou do Quebec, é geralmente positiva. Não sei até ponto essa visão reflete a realidade, mas a representação no livro também é muito boa e na tradução essa representação é enfatizada, pois reflete que a sociedade quebequense contemporânea é multicultural.

O professor comentou durante as aulas ministradas no Programa de Pós-Graduação em Estudos da Tradução, na Universidade Federal de Santa Catarina, em março de 2012, sobre a possibilidade da tradução do romance $\mathrm{Ru}$ para o português brasileiro. Na sua opinião, o que está faltando para que esse projeto se concretize?

M. C.: Primeiramente, o interesse por parte de uma editora brasileira. Excertos do início da tradução feitos por uma tradutora mineira, radicada no Quebec há muitos anos, já foram entregues para uma editora brasileira, mas ainda não sabemos se o projeto vai interessar ou não à editora do Rio de Janeiro. A editora precisa pagar os direitos para o mercado brasileiro, mas o Conselho das Artes do Canadá financia quase 75\% dos custos da tradução. A editora precisa, no entanto, ter a certeza de que o livro vai vender, o que eu acredito que aconteça, tendo em vista o sucesso de vendas que teve na Europa, por exemplo.

No seu ponto de vista, qual a "barreira” em traduzir obras literárias?

M. C.: No mundo atual, literatura traduzida é, infelizmente, algo bem europeu. A maioria das traduções literárias é feita principalmente na Espanha, Itália, França e Alemanha. No entanto, 
a Coreia do Sul é o segundo país que mais traduz literatura francesa, ficando atrás apenas da Itália.

${ }^{1}$ Ph.D. em Tradução - Tradutologia pela Universidade de Montreal, atualmente professor da Universidade de Ottawa, membro da Faculdade de Estudos Superiores e Pós-Graduação da Universidade.

${ }^{2}$ Graduada em Letras-Francês pela Universidade Federal de Santa Catarina e mestranda no curso de PósGraduação em Estudos da Tradução da mesma instituição.

${ }^{3}$ Graduada em Letras Português/Inglês pela Universidade Estadual de Maringá. Especialista em ensino de língua inglesa pela Universidade Estadual de Londrina e mestranda no curso de Pós-Graduação em Estudos da Tradução da Universidade Federal de Santa Catarina.

${ }^{4}$ Em 1977, a província de Quebec, sob o governo de René Lévesque, tornou o francês a única língua oficial da província, e em 1980, o Quebec realizou um referendo para a independência da mesma - no plebiscito realizado em Quebec, 60\% dos votantes não aprovaram o referendo, e o Quebec continuou oficialmente no Canadá. Numa segunda votação por um segundo referendo para a independência da província, em 1995, o número de votantes que votaram por continuar no Canadá havia caído para $50.3 \%$.

${ }^{6}$ Incêndios é uma produção canadense indicada ao Oscar de Melhor Filme Estrangeiro em 2010. Ele é a adaptação da peça homônima do dramaturgo (e também diretor) libanês Wadji Mouawad, que vive entre o Canadá e a França, e que escreve em francês.

7 Ying Chen nasceu em Shangai em 1961, mas atualmente mora em Vancouver, Canadá. Autora de 10 romances publicados em língua francesa, seu primeiro livro, La mémoire de l'eau, relata a história da China contemporânea através do olhar de mulheres de várias gerações. 